\title{
EXIT STRATEGY PERCEPATAN PENANGANAN CORONA VIRUS DISEASE 2019 (COVID-19)
}

\author{
Oleh: \\ Abdurahman'1, Abubakar Basyarahil2, Sukron Ma'mun², \\ Dosen Fakultas IImu Administrasi Universitas Madura, Jawa Timur, Indonesia \\ abdurahman@unira.ac.id
}

\begin{abstract}
Abstrak
Penyebaran corona virus disease (covid-19) belum menunjukkan tanda-tanda akan menurun. Laporan WHO 19 agustus 2020 angka terkonfirmasi positif lebih dari 22 juta dan meningggal 778.000 orang, sedangkan di Indonesia sendiri per 19 agustus kasus 144.945 terkonfirmasi, 98.657 sembuh dan 6.346 meninggal. Wilayah Jawa Timur yang terkonfirmasi per 18 agustus 28.551, sembuh, 21.632, dan 2.055 , serta dirawat 4.864. Sedangkan di kabupaten sampang pasien positif pertanggal 18 agustus mencapai 219 Terkonfirmasi, 13 Meninggal, 186 sembuh dan 18 dirawat. Kabupaten Sampang merupakan daerah terakhir di Jawa Timr yang diketahui ada pasien positif dari klaster pasar tradisional, sebelumnya daerah ini selama kurang lebih dua bulan bersama kabupaten sumenep bertahan dengan zona hijau.
\end{abstract}

Kata Kunci : Exit Strategi, Covid-19, Kabupaten Sampang

Abstract

The spread of the corona virus disease (covid-19) has not shown any signs of decreasing. The WHO report on August 19, 2020, the number confirmed positive was more than 22 million and 778,000 people died, while in Indonesia alone as of August 19, 144,945 cases were confirmed, 98,657 recovered and 6,346 died. East Java region that was confirmed as of August 18, 28,551, healed, 21,632, and 2,055, and 4,864 treated. Meanwhile, in Sampang district, positive patients on August 18 reached 219 confirmed, 13 died, 186 recovered and 18 were treated. Sampang Regency is the last area in East Java where there are known positive patients from the traditional market cluster, previously this area for about two months with the Sumenep Regency survived in a green zone.

Keywords: Exit Strategy, Covid-19, Sampang

\section{PENDAHULUAN}

Penyebaran corona virus desease (covid-19) belum menunjukkan tanda-tanda akan menurun. Laporan WHO 19 agustus 2020, kasus terkonfirmasi di dunia 22.079.925 (22 juta) dan meninggal 778.102 kasus (Kompas/8/20), hal ini menunjukan bahwa penanganan Pencegahan penyebaran covid19 di dunia dengan melonggarkan aktivitas sosial kemasyarakat dan ekonomi untuk meningkatkan kekebalan kelompok tidak tercapai, sedangkan laporan gugus tugas percepatan penaganan covid-19 di Indonesia pertanggal 19 agustus 2020 angka terkonfirmasi mencapai 144.945, sembuh 96.306 dan meninggal 6.346. Pembatasa Sosial Berskala melalui Peraturan Pemerintah Republik Indonesia Nomor 21 Tahun 2020 tentang Pembatasan Sosial Berskala Besar Dalam Rangka Percepatan Penanganan Corona virus Disease 2019 (COVID-19) dan pembentukan gugus tugas percepatan penaganan covid-19 sendiri melalui Peraturan Presiden Nomor 7 tahun 2020 tentang Gugus Tugas Percepatan Penanganan Corona Virus Desease tidak cukup efektif mencegah penyebaran covid-19. Data perkembangan penanganan covid-19 di Indonesia sebagiamana gambar 1.1 berikut ini:

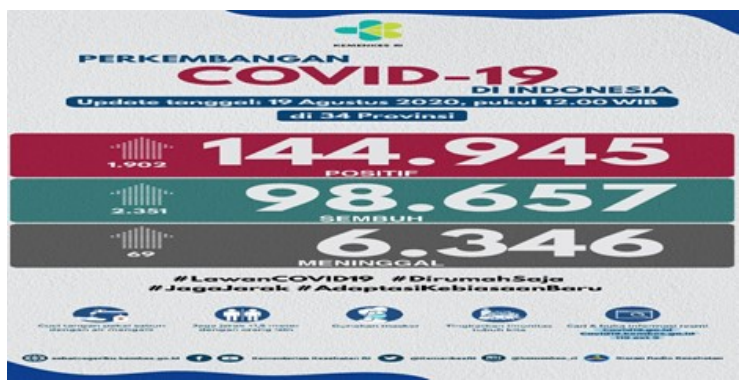


Gambar 1. Pembuatan pakan ternak entok secara tradisional/manual

Di Jawa Timur sendiri pada 19 agustus 2020 kasus terkonfirmasi 28.886, meninggal 2.074, sembuh 22.076 dan dirawat 4.732 Gambar 1.2 menunjukkan gambaran secara umum penaganan Corona virus Disease 2019 (Covid-19) di Jawa Timur:

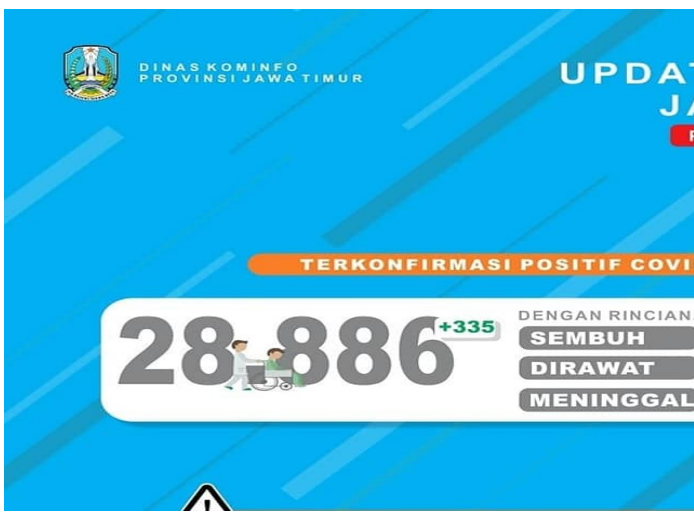

Wilayah Jawa Timur menjadi epicentrum kedua setalah DKI, sedangkan di Kabupaten Sampang pertanggal 19 agustus 2020 kasus terkonfirmasi 221, meninggal 13 dan sembuh 194 orang, padahal daerah ini merupakan daerah terakhir yang diketahui ada pasien positif dari klaster pasar tradisional, sebelumnya daerah kabupaten sampang selama kurang lebih satu bulan bersama kabupaten sumenep bertahan dengan zona hijau. Gambar 1.3 merupakan kondisi terkini kasus covid-19 di kabupaten.

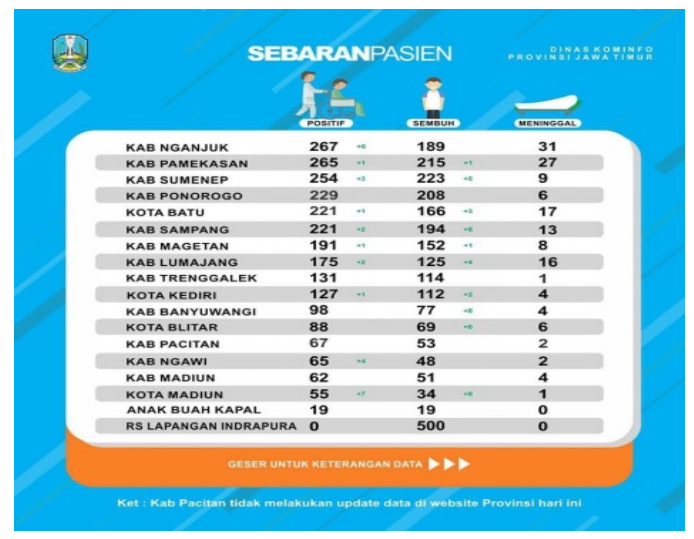

Diawal-awal penyebaran covid-19 pemerintah daerah kabupaten sampang bersama FORKOPIMDA (forum koordinasi pimpinan daerah) aktif membentuk kampung dan desa siaga dalam upaya mencegahan penyebaran covid-19 dan selama kurang lebih satu bulan berhasil bertahan dengan zona hijau disaat daerah-daerah lain di jawa timur sudah zona merah. Pembentukan kampung dan desa siaga untuk mengontrol masuknya para perantau baik dari dalam negeri ataupun dari luar negeri, karena hamper 10 penduduk kabupaten sampang mengadu nasib dengan merantau ke kota-kota besar dalam negeri ataupun negara-negara sahabat. Fokusnya pemerintah daerah dan FORKOPIMDA membentuk kampung dan desa siaga ternyata membawa petaka ketika diketahui pasien pertama positif covid-19 adalah klaster pasar ditengah-tengah kota. Hal tersebut menyebabkan penyebaran covid-19 sulit untuk dicegah sehingga pasien positif di Kabupaten Sampang terus mengalami peningkatan.

Percepatan penanganan covid-19 orang terkonfirmasi terus mengalami peningkatan. Fakta-fakta diatas menunjukan strategi percepatan penanganan covid-19 belum efektif, sehingga penelitian ini memfokuskan penelitian pada "bagaimana strategi percepatan penanganan covid-19 di Kabupaten Sampang Sejak Kabupaten Sampang ditetapkan menjadi zona merah FORKOPIMDA dengan Bupati Sampang Genjar membentuk Kampong dan Desa Tangguh walaupun sebenarnya tidak cukup efektif dalam mencegah penyebaran covid-19 ini, karena sampai tanggal 18 agustus 2020 berdasarkan rilis data dari tugas gugus. Penelitian pengabdian ini dianalisis berdasarkan konsep dan regulasi penanganan wabah disuatu negara atau wilayah.

\section{METODE PELAKSAAN}

\section{Persiapan Pelaksanaan}

Program pelaksanaan pegabdian ini sukses, karena sebelum pelaksanaan kegiatan dimulai terlebih dahulu dikoordinasikan dengan semua pihak terutama dengan gugus tugas percepatan penanganan covid-19. Keberhasilan penelitian pegabdian ini diharapkan berkontribusi secara konseptual dan aktual terkait penaganan percepatan covid-19.

2. Tahapan Pelaksanaan

Metodologi kegiatan pengabdian ini berbentuk forum Discussion Group (FDG) sosialisasi protap kesehatan kepada masyarakat, terutama tempat-tempat kerumunan, seperti tempat ibadah, tempat 
belajar, pasar dan swalayan, pentingnya menjaga kebersihan dan kesehatan dengan berolah raga. Lokasi Pengabdian di Kabupaten Sampang sedangkan tahapantahapan pelaksanan sebagaimana table 2.1 berikut.

Tabel. 1 Tahapan Pelaksanaan

\begin{tabular}{|c|c|}
\hline Kegiatan & Luaran \\
\hline 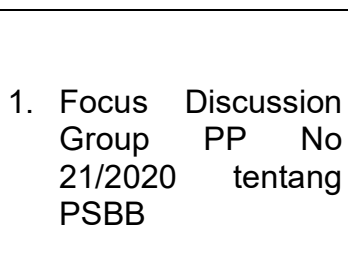 & $\begin{array}{l}\text { Sosialisasi dan } \\
\text { Edukasi. } \\
\text { Meinkatnya } \\
\text { kesadaran public } \\
\text { terhadap bahaya } \\
\text { Covid-19 }\end{array}$ \\
\hline $\begin{array}{l}\text { 2. Focus Discussion } \\
\text { Group Perpres No } \\
82 / 2020 \text { tentang } \\
\text { Komite } \\
\text { Penanganan } \\
\text { Covid-19dan } \\
\text { Pemulihan } \\
\text { Ekonomi Nasonal }\end{array}$ & $\begin{array}{l}\text { Meningkatnya } \\
\text { kesadaran dan } \\
\text { perilaku disiplin } \\
\text { masyarkat dalam } \\
\text { melakukan } \\
\text { aktivitas sehari- } \\
\text { sehari. }\end{array}$ \\
\hline $\begin{array}{l}\text { 3. Sosialsasi Protokol } \\
\text { Kesehatan }\end{array}$ & $\begin{array}{l}\text { Meningkatnya } \\
\text { kesadaran } \\
\text { masyarakat } \\
\text { dalam menjaga } \\
\text { kebersihan } \\
\text { lingkunga } \\
\text { sehingga dapat } \\
\text { mengurangi } \\
\text { penularan covid- } \\
19 .\end{array}$ \\
\hline $\begin{array}{l}\text { 4. Focus Discussion } \\
\text { Group Inpres No } \\
6 / 2020 \text { tentang } \\
\text { Peningkatan dan } \\
\text { Disiplin Hukum } \\
\text { Penegakan Hulam } \\
\text { Protokol } \\
\text { Kesehatan dalan } \\
\text { Pencegahan } \\
\text { Covid-19 }\end{array}$ & $\begin{array}{l}\text { Dibentuknya } \\
\text { Satgas } \\
\text { Implenteasi } \\
\text { Inpres oleh Bupati } \\
\text { dan Wakil Bupati } \\
\text { Sampang pada } \\
\text { 18/08/20. }\end{array}$ \\
\hline
\end{tabular}

Dalam melakukan kegiatan FDG protokol kesehatan kepada masyarakat dan tokoh agama kami bekerjasama dengan petugas Gugus Tugas Percepatan Penanganan Covid-19 dan Relawan. Upaya sosialiasi terus kami lakukan secara inten terutama ditempat-tempat kerumunan yang sangat berpotensi terjadinya penyebaran vovid-19.

Ada pendapat para Ahli epidemologi tentang penyebaran Covid-19 dan terkonfirmasi WHO pada /9/7/2020 bahwa covdi-19 bisa melalui udara, untuk menyikapi hal-hal tersebut Pemerintah Daerah Kabupaten Sampang membuat beberapa langkah taktis sebagai strategi pencegahan penyebaran Virus Corona Covid-19 supaya tidak menyebar secara luas di masyarakat. Upaya-upaya pencegahan yang dilakukan pemerintah hingga ke tingkat RT/RW, seperti pembentukan kampung dan desa siaga, kampung dan desa tangguh guna memberikan pemahaman dan antisipasi terhadap penularan covid-19 yang terus mengalami Ionjakan. Pada sisi lain pandemi covid-19 ini menjadi ancaman serius bagi pemerintah dan Masyarakat, terutama pada sektor ekonomi dan pendidikan yang terus mengalami kontruksi negatif.

Penelitian Ini menggunakan metode analisis, dimana kontent analisis dibatasi pada keputusan kepala daerah bersama satgas gugus tugas percepatangan penanganan covid19 melalui siaran pers, surat kabar yang menyampaikan informasi terkait beberapa langkah taktis yang diambil oleh kepala daerah bersama satgas gugus tugas percepatangan penanganan covid19 dan upaya-lupaya langsung oleh pemerintah, seperti pembagian masker, penyemprotan disinfektan, sanitasi, dan pembatasan sosial besar besaran. Tujuan penelitian ini untuk memberikan informasi dan edukasi kepada pemerntah dan masyarakat dalam menghadapi covid-19 dan pencegahannya.

HASIL DAN PEMBAHASAN

Pelaksanaan program pegabdian, Strategi Percepatan Penanganan Corona Virus Disease 2019 (Covid-19) di Kabupaten Sampang Madura. Satgas Gugus Tugas Percepatan Penanganan Covid-19 telah banyak melakukan stategi upaya Pencegahan dan penanganan penularan covid-19 melalui teknik informatif, edukatif, persuasif dan preventif. Akan tetapi upaya pemerintah daerah tersebut banyak ditanggi dingin oleh masyarakat bahkan tokoh-tokoh agama yang tidak meyakini adanya virus covid-19., sehingga himbauan untuk jaga jarak, memakai masker, cuci tangan dan menghindari kerumunan tidak sepenuhnya diikuti oleh masyarakat bahkan bias dikatakan tingkat kepatuhan masyarakat sampang sangat rendah. Satgas gugus tugas 
percepatan penanganan covid-19 belum memaksimalkan perannya dalam menggunakan strategi secara komprehensif bagi seluruh elemen masyarakat. Hal ini karena tidak adanya upaya komunikasi melalui temapat-tempat ibadah, sekolah, pesantren dan tokoh masyarakat.

Penyebaran covid-19 di Kabupaten Sampang terus mengalami peningkatan terutama setelah pelaksanaan hari raya idul fitri, dugaan kuat penyebaran covid-19 di Kabupaten Sampang karena informasi yang disampaikan oleh satgas gugus tugas percepatan penanganan covid-19 belum teringtrasi dengan sistem informasi pemerintahan kecamatan, kelurahan dan desa, disisi lain banyak informasi yang bias yang sebarkan melalui medsos dan influenser yang tidak dapat difilter oleh petugas satgas.

Maksud informasi bias di atas adalah informasi mengenai bahaya penyebaran covid-19 selalu ada infomasi antonym yang juga disertai analisis ilmiah dan juga meyakinkan terhadap masyarakat dan kalangan tokoh termasuk tokoh-tokoh pesanteren. Disisi lain kesehatan masyarakat telah terjamin melalui Konstitusi Negara Indonesia. Dengan demikian dapat memiliki hak yang sama dimata hukum untuk tujuan keselamatan masyarakat. Menyikapi adanya pandemi Covid-19 yang telah menyebar di 14 kecamatan, dan semua daerah yang berbatasan langsung dengan kabupaten sampan seperti Kabupaten Bangkalan dan Kabupaten Pamekasan terus mengalmi peningktan positif covid-19. disamping itu, problematika yang terjadi akibat adanya Covid-19 yaitu kurang optimal kordinasi antar pemerintah provinsi dan 4 kabupaten di Madura yang berdampak semakin tersebarnya virus Covid-19 karena tidak pencegahannya tidak terintegrasi. Landasan teori yang penulis gunakan yaitu teori exit strategy (Laksono, 2005) dengan tiga pendekatan. 1) phasing down. 2) phasing out. 3) phasing over. Kemudian metode yang digunakan adalah naratif ekploratif yakni metode dengan pendekatan studi kasus dan narasi. Maka perlu adanya strategi kebijakan yang dapat pemerintah berikan agar bisa keluar dari ancaman Covid-19.

Secara historical context, Covid-19 merupakan penyakit menular yang mulai berkembang di tahun 2019 yang sampai saat ini menjadi permasalahan utama di seluruh dunia. Awal keberadaannya yaitu berasal dari Wuhan, Tiongkok yang disebabkan berasal dari salah satu hewan liar yaitu kelalawar.5
Dampak dari terkenanya Covid-19 bagi individu yang terinfeksi yaitu akan mengalami gangguan pernafasan ringan hingga dapat menyebabkan kematian (Juaningsih dkk, 2020). Pada kasus penanganan covid-19 di kabupaten Sampang, diawal-awal kepala daerah bersama tim satgas gusus tugas percepatan penanganan covid-19 terlalu percaya, karena Kabupaten Sampang satusatunya Kabupaten di Jawa Timur yang paling lama bertahan dengan zona hijau. Puja-puji terhadap kepala daerah dan satgas menimbulkan kecurigaan banyak kalangan termasuk di internal satgas sendiri, dengan munculnya istilah "Sampang Hijau Semangka". Ungkapan tersebut dimaknai oleh banyak kalangan bahwa sebenarnya Kabupaten Sampang sudah ada yang terkonfirmasi karena banyaknya TKI asal sampang yang mudik pada saat itu, tetapi karena ditutupi dengan image bahwa Kabupaten Sampang tetap zona hijau membuat aktivitas masyarakat berjalan secara normal bahkan cuek dengan informasi bahaya penyebaran covid-19. Perkembangan percepatan penanganan covid-19 di Kabupaten Sampang pertanggal 19 agustus 2020 sebagaimana gambar 3.1. di bawah:

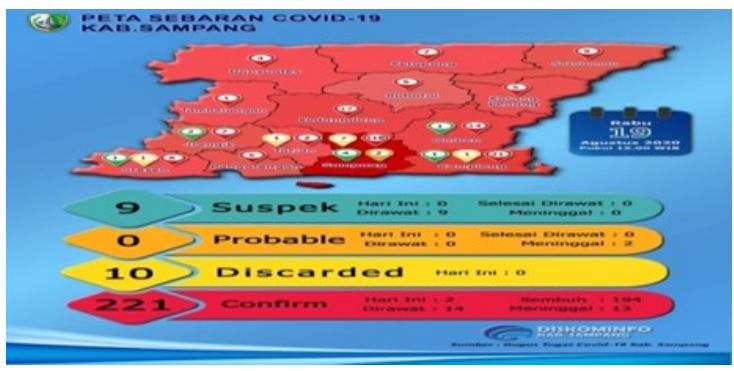

Peta penyebaran covid-19 di kabupaten terjadi pada 14 kecamatan dan pertanggal 13 agustus 2020 yang terkonfirmasi positif 221 orang, dirawat 14 orang, sembuh 194 dan meninggal 13 orang. Disisi lain pertanggal 10 agustus kabupaten sampang berdasarkan peta sebaran covid-19 Provinsi Jawa Timur lepas dari zona merah menjadi zona kuning.

Percepatan Penanganan Covid-19 di Kabupaten/Kota mengikuti interuksi Satgas Gugus Tugas Percepatan Penanganan Covid19 pemerintah pusat, dimana pemberlakuan menuju kebiasaan baru atau dikenal dengan istilah populernya "new normal" juga diikuti oleh pemerintah daerah termasuk kabupaten sampang, hasil pengamatan dan analisis data dalam penelitian ini menunjukkan bahwa pemberlakuan terhadap new normal dan 
ditariknya interuksi kapolri tentang larangan berkerumun merupakan bentuk perlawanan terhadap ancaman penyebaran covid-19 yang telah hampir melumpuhkan sendi-sendi kehidupan masyarakat, seperi pendidikan, ekonomi, transportasi, pariwisata dan banyaknya rumah-rumah sakit yang tutup, bahkan di kabupaten sampang sendiri berdasarkan pengamatan peneliti, 5 puskesmas yang pernah ditutup karena tenaga medisnya terpapar covid-19, puskesmas-puskesmas yang pernah ditutup diantaranya, puskesmas kecamatan karang penang, puskesmas banyuanyar, puskesmas banyuates, puskesmas sokobanah dan puskesmas komuning, ditutupnya puskesmaspuskesmas tersebut karena klaster medis merupakan kalster kedua paling banyak setelah kelaster pasar. Jika penerapan new normal tersebut ditinjau dari segi konsep stratgei maka akan ditemukan pola bahwa hal merupakan Exit strategy supaya pemerintah tidak terkunkung dengan keadaan yang tidak kunjung pasti akibat wabah covid-19 ini.

Exit strategy sendiri merupakan sebuah program yang bermaksud menarik keputusan awal atau sumberdaya namun tetap menjamin pencapain program tidak berkurang dan perkembangan pencapaian tujuan tetap berlangsung (Laksono, 2005). Bila mana konsep ini dikaitkan dengan keputusan pemerintah untuk memberlakukan kebiasan baru atau new normal disaat kasus positif covid-19 terus mengalami kenaikan ini merupakan bentuk atau gambaran eksplesit dari exit strategi, dimana pemerintah daerah kabupaten Sampang membolehkan kembali aktivitas sosial kemasyarakatan, seperti pengajian, haflatul imtihan di pondok-pondok pesantren, resepsi pernikahan dan aktivitas ekonomi akan tetapi tetap menggunakan protokal kesehatan. Tujuan untuk mencegah penyebaran covid-19 tetap menjadi prioritas dengan mematuhi protokol kesehatan seperti cuci tangan dengan air mengalir, menggunakan handsanitezer, jaga jarak dan menggunakan masker terus menjadi program satgas gusus tugas percepatan penanganan covid-19 di Kabupaten Sampang.

Semangat pemerintah daerah Kabupaten Sampang dalam penanganan covid-19 tidak didukung oleh soliditas satgas itu sendiri, karena bebagai informasi yang diadapat oleh peneliti, bahwa tim satgas sendiri tidak solid, ada semacam kebukubuan, sehingga hal berdampak pada program-program penanganan covid-19 seperti bantuan sosial tunai (BST) daerah belum tersalurkan secara tepat. Informasi lain, bahwa satgas gugus telah membeli aplikasi pemantauan kasus covid-19 dari salah perguruan tinggi di jawa timur, tetapi belum dapat diaplikasikan sehingga sempat menjadi bahan telah DPRD Kabupaten Sampang dalam gelar pansus.

Dalam penangan Covid-19, kebijakan pemerintah justru mengalami disharmonisasi antara Kebijakan yang dibuat oleh pemerintah daerah dengan kebijaka Pemerintah Desa. Perbedaan tersebut dimulai ketika beberapa desa menetapkan larangan berkeruman terutama di dalam kota namun mayoritas pemerintah desa lain membiarkan aktivitas secara normal. Kebijakan yang diterapkan oleh Pemerintah Daerah yang masih menjadi kejanggalan di kalangan masyarakat, karena himbauan yang dibuat masih bersifat tidak mengikat dan sepertinya pemerintah daerah tidak bisa membatasi aktivitas masyarakat karena khawatir tidak dapat memberikan solusi terhadap pemenuhan kebutuhan selama masa PSBB serta terkesan Pemerintah Pusat dan Daerah tidak punya cukup anggaran untuk penganganan covid19 , sehingga harus memotong sampai 30 persen anggaran pembangunan di setiap Organisasi Perangkat Daerah dan pemerintah pusat menarik dana sharing ke daerah sampai 50 persen.

Untuk memutus mata rantai penyebaran covid-19 dengan melalui disiplin, tanggung jawab dan kesadaran holistik. Perubahan perilaku masyarakat akan menjadi kekuatan untuk menekan penyebaran covid19 ini, karena vaksin belum bisa dipastikan validitasnya, hal ini sebagaimana disampaikan oleh ketua Satgas Percepatan Penanganan Covid-19 Doni Monardo, menurutnya, perubahan perilaku masyarakat adalah menumbuhkan kesadaran kolektif, tanggung jawab kolektif dan disiplin kolektif dari seluruh elemen bangsa. (Kompas, 8/2020).

Pencegahan penyebaran covid-19 paling efektif melalui sosialisasi yang baik dan tepat sasaran kepada masyarakat, sehingga diperlukan kehadiran para pemimpin publik mulai dari pemerintah pusat, provinsi, kabupaten/kota dan kepala desa sebagai komunikator tentang edukasi disiplin mematuhi protokol kesehatan. Hal inilah yang akan menjadi exit strategy percepatan penanganan covid-19 dari pada pemerintah mengkungkung masyarakat dalam rumah tetapi tidak bisa bertanggung jawab terhadap kebutuhan pokoknya. 
Peran exit startagy telah banyak ditemukan diberbagai Negara dalam menghadapi pandemi covid-19 ini, keberhasilan Negara-negara tersebut perlu menjadi referensi bagi pemerintah daerah kabupaten sampan dalam menjalankan tugas untuk memutus mata rantai covid-19 ini. Ada 3 langkah dalam pendekatan dalam konsep exit strategy yang akan dibahas satu-satu dalam percepatan penanganan covid-19 di Kabupaten Sampang:

\section{Phasing Down}

Pada bagian ini, adalah bagaimana Pembatasan Sosial Besar-besaran atau social distancing dilonggarkan, aktivitas ekonomi seperti petokoan, pasar-pasar tradisonal, kegiatan sosial seperti hajatan pernikaha, acara formal pemerintah yang mengundang banyak orang, pengajian, dan tempat-tempat peribadatan serta kegiatan-kegiatan sosilanya lainya dibiarkan berjalan normal dengan mematuhi protokol kesehatan, termasuk pada dunia pendidikan, dimana pemerintah pusat melalui SKB 4 menteri yaitu menteri pendidikan dan kebudayaan, menteri agama, menteri dalam negeri dan menteri kesehatan republik Indonesia mengeluarkan keputusan bersama terkait penyelenggaraan pendidikan tatap muka terbatas masa pandemic covid-19, salah satu poinya adalah, memperbolehkan daerah zona hiau dan kuning untuk membuka pembelajaran tatap muka terbatas dengan maksimal $50 \%$ satu kali tatap muka dan diatur shif oleh satuan sekolah masingmasing, serta mematuhi semua protokol kesehatan secara ketat.

Ridha (2020) dalam tulisan opini geotimes 20 agustus mengatakan, bahwa kasusu penyebaran pandemi covid-19 masih sangat tinggi, baik secara global maupun nasional. Dampak yang ditimbulkan dari pandemi covid-19 pada sector pendidikan berdasarkan rilis data PBB bahwa sekitar 94 persen atau 1,58 milyar perserta didik di 200 negara di dunia, mulai dari jenjang pendidikan usia dini hingga perguruan tinggi terkena dampak pendemi covid-19. Hal ini juga berdampak pada sektor ekonomi, jasa transfortasi dan rumah-rumah kos. Sehingga pemerintah Indonesia perlu mengambil opsi terkait PSBB yang meinimbulkan gejolak sosial yang membahayakan terhadap keamanan nasional. Salah satu opsi yang diambil oleh pemerintah Indonesia termasuk kebijakan yang dilakukan oleh pemerintah daerah kabupaten sampang adalah membuka kembali sekolah dengan mengunakan protap kesehatan secara ketat.

Disisi lain pemerintah daerah kabupaten sampan sudah mulai mengurangi bantuan terhadap masyarakat, dan mengalihkan pada sektor bisnis dan UMKM. Anggaran yang sudah terlanjur dialokasikan untuk percepatan penanganan covid-19 akan direlokasi untuk memulihkan sektor ekonomi, pariwisata, UMKM serta infrastruktur pendukung. Hal ini dilakukan sebagai bentuk jalan artenatif supaya masyarakat tidak terbelengu dengan penyebaran covid-19 yang berdampak terhadap keamanan nasional.

\section{Phasing Out}

Pada pase ini dana-dana bantuan sosial dari pemerintah, perusahaan, dan lembaga kemasyarakatan serta elemen masyarakat sudah mulai dikurangi dan dialihkan kepada pemulihan ekonomi, insfrastruktur dan penelitian dan pengembangan vaksin, misalkan yang dilakukan bos microsof Bill Gate yang akan mendonasikan sekitar 2,2 triliun untuk Negara-negara miskin dan berkembang untuk menemukan dan mendistribukan vaksin covid-19 murah dan terjangkau. Pemerintah daerah kabupaten Sampang melakukan hal yang hampr sama, yaitu bantuan yang telah dianggarkan melalui APBD sebesar 147 miliar tidak sepenuhnya dialokasikan kepada masyarkat terdampak pandemic covid-19, hanya skitar $30 \%$ yang sudah digunakan untuk operasional, penanganan pasien, pembentukan posko siaga serta pembentukan kampong dan desa tangguh, sedangkan $60 \%$ sisanya akan masuk pada program PAK 2020 untuk pemulihan ekonomi dan pembangunan infrastruktur. Bantuan-bantuan perorangan ataupun perusahaan dipastikan hampir tidak ditemukan lagi.

\section{Phasing Over}

Pase ini sebenarnya sudah sejak bulan mei telah disampaikan oleh pemerintah pusat melalui Menko Airlangga Hartanto, yaitu alternatif tahapan penyelsaian covid-19 akan dimulai dari dibukanya kembali mall-mall pembelanjaan, diikuti oleh pabrikan, tempattempat keramian seperti pariwisata dan aktivitas ekonomi-lainnya termasuk aktivitas sosial kemasarakatan. Tahapan penyelesaian covid-19 tersebut untuk menyelematkan perekonomian Indonesia yang mengalami demand shock sehingga pada saat covid-19 sudah dapat dikendalikan maka ekonomi 
indinesia secara keseluruhan tetapu tumbuh sehat (Mediaindonesia.com.7/5/20)

Pembatasan Sosial Berskala Besar (PSBB) merupakan kebijakan pemerintah yang dikeluarkan melalui Peraturan Pemerintah Republik Indonesia Nomor 21 Tahun 2020 tentang Pembatasan Sosial Berskala Besar Dalam Rangka Percepatan Penanganan Corona virus Disease 2019 (COVID-19). Pembatasan Sosial Berskala Besar (PSBB) adalah pembatasan kegiatan tertentu penduduk dalam suatu wilayah yang diduga terinfeksi Corona Virus Disease 2019 (COVID-19) sedemikian rupa untuk mencegah kemungkinan penyebaran Corona Virus Disease 2019 (COVID-19).

Peraturan diatas mengalami perubahan melalui Peratutan Presiden Republik Indonesia Nomor 82 Tahun 2020 tentang Komite Penanganan Corona Virus Disease 2019 (COVID-19) dan Pemulihan Ekonomi Nasional. Perubahan peraturan tersebut jelas menunjukan pemerintah mengalihkan fokus penanganan covid-i9 pada pemulihan sektor ekonomi sebagai dampak dari penyebaran covid-19. Karena komposisi komite dalam peraturan Presiden tersebut di ketua oleh Menteri Badan Usaha Milik Negara (BUMN) Erik Tohir. Tentu perubahan ini sebagai respon dari gejala sosial dan ekonomi nasional yang mengalami kontraksi sangat parah.

Dampak dari peraturan diatas juga berimplikasi pada penanganan kasus covid19 di daerah, termasuk di Kabupaten Sampang, dimana penanganan kasus covid19 tidak lagi fokus pada peroragan yang memiliki gejala probable, suspect dan terkonfirmasi, tetapi lebih pada gejala sosial ekonomi yang mengalami pelemahan. Pada sisi lain perubahan penanganan covid-19 ini merupakan bentuk reaksi pemerintah keluar secara berlahan dari strategi awal percepatan penanganan covid-19 dan dipasrahkan kepada individu dalam memutus mata rantai penyebaran covid-19 ini, pemerintah hanya bertindak sebagai kontrol sikap disiplin masyarakat terhadap kepatuhan proţagan kesehatan sebagaimana diatur dalam Instruksi Presiden Republik Indonesia Nomor 6 Tahun 2020 tentang Peningkatan Disiplin dan Penegakan Hukum Protokol Kesehatan dalam Pencegahan dan Pengendalian Corona Virus Disease 2019 (COVID-19), untuk menjalankan Inpres tersebut Buapti dan Wakil Bupati Sampang tanggal 18 agustus membentuk tim yang terdiri dari unsur Kodim, Polres, Satpol PP, dan aparatur daerah guna mendorong sikap tanggang jawab dan disiplin masyarakat dalam memutus mata rantai penyebaran covid- 19 .

Salah satu poin dalam Inpres Nomor 6 tahun 2020 tersebut adalah memuat sanksi terhadap pelanggaran penerapan protokol kesehatan dalam pencegahan dan pengendalian Corona Virus Disease 2019 (COVID19) yang dilakukan oleh perorangan, pelaku usaha, pengelola, penyelenggara, atau penanggung jawab tempat dan fasilitas umum. Adapun sanksi dimaksud dalam Inpres tersebut berupa: 1) teguran lisan atau teguran tertulis; 2) kerja sosial; 3) denda adminisratif; atau 4) penghentian atau penutupan sementara penyelenggaraan usaha.

\section{KESIMPULAN DAN SARAN}

\section{Simpulan}

Dari hasil pembahasan diatas dapat disimpulkan bahwa pemerintah daerah kabupaten sampang telah melakukan percepatan penanganan covid-19 melalui pembentukan satgas gugus tugas sebagai bentuk implementasi Peraturan Pemerintah Republik Indonesia Nomor 21 Tahun 2020 tentang Pembatasan Sosial Berskala Besar Dalam Rangka Percepatan Penanganan Corona virus Disease 2019 (COVID-19), Peratutan Presiden Republik Indonesia Nomor 82 Tahun 2020 tentang Komite Penanganan Corona Virus Disease 2019 (COVID-19) dan Instruksi Presiden Republik Indonesia Nomor 6 Tahun 2020 tentang Peningkatan Disiplin dan Penegakan Hukum Protokol Kesehatan dalam Pencegahan dan Pengendalian Corona Virus Disease 2019 (COVID-19), hal ini merupakan exit strategy dalam memutus mata rantai penyebaran covid-19 dan membentuk kebiasaan prilaku hidup baru dengan mematuhi disiplin protokol kesehatan bagi seluruh elemen masyarkat Kabuapten Sampang baik yang dilakukan oleh perorangan, pelaku usaha, pengelola, penyelenggara, atau penanggung jawab tempat dan fasilitas umum.

\section{Saran}

Saran yang dapat direkomendasikan dalam penelitian pengabdian ini adalah; 1). Pemerintah daerah Kabupaten Sampang hendaknya merangkul tokoh agama dan masyarakat dalam mensosialisasikan disiplin protokol kesehatan, 2). Memanfaatkan tempat-tempat ibadah sebagai ujung tombak sosialisasi dan penerapan protokol kesehatan, 3) memanfaatkan tempat-tempat keramaian seperti pasar, pertokoan, restoran 
dan kafe sebagai mitra penerapan disiplin protokol kesehatan, dan 4). Melakukan tindakan pencegahan dan penegakan yang tegas bagi individu, lembaga dan komunitas yang melanggar disiplin protokol kesehatan dengan menunda pencairan bantuan.

\section{Daftar Pustaka}

Juaningsih, Consuello, Tarmidzi dan Nurirfan. 2020, Optimalisasi Kebijakan Pemerintah Daerah dalam Penanganan Covid-19 terhadap Masyarakat Indonesia. Jurnal Sosial \& Budaya Yar-I FSH UIN Syarif hidayatullah Jakarta. Vol.7 No.6,pp.509-518.

(2005) Laksono, Exit Strategy-C-SAFE Practical Guidelines.

The Geotimes. Muhammad Ridha. Covid-19, Sekolah dan Bencana Generasi. 20/08/2020.

\section{Peraturan Perundang Undangan}

Peraturan Pemerintah Republik Indonesia Nomor 21 Tahun 2020 tentang Pembatasan Sosial Berskala Besar Dalam Rangka Percepatan Penanganan Corona virus Disease 2019 (COVID-19).

Keputusan Presiden Republik Indonesia Nomor 7 Tahun 2020 Tentang Gugus Tugas Percepatan Penanganan Corona virus Disease 2019 (COVID-19).

Peratutan Presiden Republik Indonesia Nomor 82 Tahun 2020 tentang Komite Penanganan Corona Virus Disease 2019 (COVID-19).

Instruksi Presiden Republik Indonesia Nomor 6 Tahun 2020 tentang Peningkatan Disiplin dan Penegakan Hukum Protokol Kesehatan dalam Pencegahan dan Pengendalian Corona Virus Disease 2019 (COVID-19)

(2020) Sehatnegeriku.kemkes.go.id/18 Agustus 2020.

(2020) Dinas Kominfo Provinsi Jawa Timur. 18 Agustus 2020.

(2020) Dinas Kominfo Kabupaten Sampang. 18 Agustus 2020.

Mediaindonesia.com. Tahapan Exit Strategy Covid-19 yang Viral Ternyata masih Kajian. 7/5/2020

Kompas.com. Organisasi Kesehatan Dunia (WHO), Jumlah Kekebalan Kelompok yang Dibutuhkan untuk Melawan Pandemi virus Corona Semakin Sulit Dicapai. 19/8/2020.

Kompas.com Perlunya Kesadaran dan Perilaku Disiplin Koletif. 8/2020 